\title{
Scopolamine (hyoscine) for preventing and treating motion sickness (Review)
}

\author{
Spinks A, Wasiak J, Villanueva E, Bernath V
}

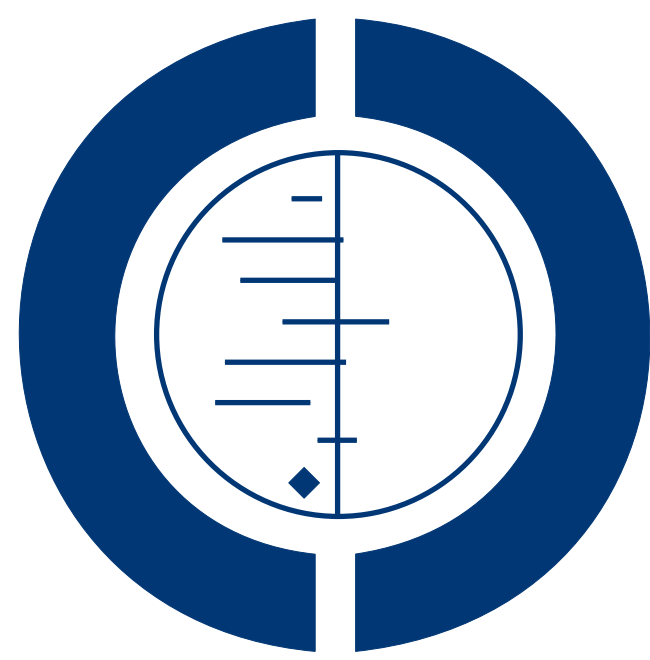

THE COCHRANE
COLLABORATION $^{\circledR}$

This is a reprint of a Cochrane review, prepared and maintained by The Cochrane Collaboration and published in The Cochrane Library 2009, Issue 1

http://www.thecochranelibrary.com

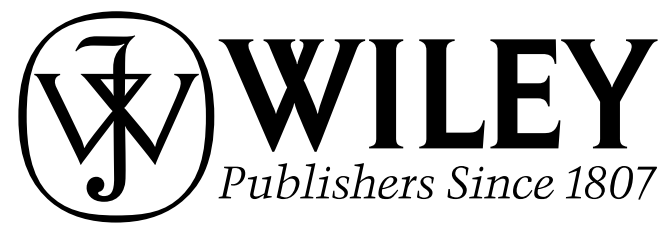

Scopolamine (hyoscine) for preventing and treating motion sickness (Review)

Copyright $\odot 2009$ The Cochrane Collaboration. Published by John Wiley \& Sons, Ltd. 


\section{TABLE OF CONTENTS}

HEADER

ABSTRACT

PLAIN LANGUAGE SUMMARY

BACKGROUND

OBJECTIVES

METHODS

RESULTS

DISCUSSION

AUTHORS' CONCLUSIONS

ACKNOWLEDGEMENTS

REFERENCES

CHARACTERISTICS OF STUDIES

DATA AND ANALYSES

Analysis 1.1. Comparison 1 Prevention of sickness symptoms (nausea), Outcome 1 Scopolamine vs placebo.

Analysis 1.2. Comparison 1 Prevention of sickness symptoms (nausea), Outcome 2 Scopolamine vs scopolamine + ephedrine.

Analysis 2.1. Comparison 2 Prevention of vomiting, Outcome 1 Scopolamine vs scopolamine + ephedrine.

Analysis 3.1. Comparison 3 Adverse event: drowsiness, Outcome 1 Scopolamine vs placebo.

Analysis 4.1. Comparison 4 Adverse events: blurred vision, Outcome 1 Scopolamine vs placebo.

APPENDICES

FEEDBACK

WHAT'S NEW

HISTORY

CONTRIBUTIONS OF AUTHORS

DECLARATIONS OF INTEREST

INDEX TERMS 


\title{
[Intervention Review]
}

\section{Scopolamine (hyoscine) for preventing and treating motion sickness}

\author{
Anneliese Spinks² ${ }^{2}$ Jason Wasiak ${ }^{1}$, Elmer Villanueva ${ }^{3}$, Vivienne Bernath ${ }^{4}$ \\ ${ }^{1}$ Victorian Adult Burns Service, The Alfred Hospital, Melbourne, Australia. ${ }^{2}$ School of Medicine, Griffith University, Meadowbrook, \\ Australia. ${ }^{3}$ Department of Rural and Indigenous Health, Monash University, Melbourne, Australia. ${ }^{4}$ Monash University Library, \\ Monash University, Victoria 3800, Australia \\ Contact address: Jason Wasiak, Victorian Adult Burns Service, The Alfred Hospital, Commercial Road, Prahran, Melbourne, Victoria, \\ 3181, Australia.J.Wasiak@alfred.org.au .jwasiak1971@gmail.com. (Editorial group: Cochrane Ear, Nose and Throat Disorders Group.) \\ Cochrane Database of Systematic Reviews, Issue 1, 2009 (Status in this issue: Edited, commented) \\ Copyright (C) 2009 The Cochrane Collaboration. Published by John Wiley \& Sons, Ltd.
}

DOI: 10.1002/14651858.CD002851.pub3

This version first published online: 18 July 2007 in Issue 3, 2007. Re-published online with edits: 21 January 2009 in Issue 1, 2009. Last assessed as up-to-date: 17 May 2007. (Help document - Dates and Statuses explained)

This record should be cited as: Spinks A, Wasiak J, Villanueva E, Bernath V. Scopolamine (hyoscine) for preventing and treating motion sickness. Cochrane Database of Systematic Reviews 2007, Issue 3. Art. No.: CD002851. DOI: 10.1002/14651858.CD002851.pub3.

\section{A B S T R A C T}

\section{Background}

Motion sickness - the discomfort experienced when perceived motion disturbs the organs of balance - may include symptoms such as nausea, vomiting, pallor, cold sweats, hypersalivation, hyperventilation and headaches. The control and prevention of these symptoms have included pharmacological, behavioural and complementary therapies. Although scopolamine (hyoscine) has been used in the treatment and prevention of motion sickness for decades, there have been no systematic reviews of its effectiveness.

\section{Objectives}

To assess the effectiveness of scopolamine versus no therapy, placebo, other drugs, behavioural and complementary therapy or two or more of the above therapies in combination for motion sickness in persons (both adults and children) without known vestibular, visual or central nervous system pathology.

\section{Search strategy}

The Cochrane Ear, Nose and Throat Disorders Group Specialised Register, the Cochrane Central Register of Controlled Trials (The Cochrane Library, Issue 2, 2007), MEDLINE (OVID, 1966 to May 2007), EMBASE (1974 to May 2007) CINAHL (OVID, 1982 to May 2007) and reference lists of retrieved studies were searched for relevant studies. No language restrictions were applied. The date of the last search was May 2007.

\section{Selection criteria}

All parallel-arm, randomised controlled trials (RCTs) focusing on scopolamine versus no therapy, placebo, other drugs, behavioural and complementary therapy or two or more of the above therapies in combination were included. Outcomes relating to the prevention of onset or treatment of clinically-defined motion sickness, task ability and psychological tests, changes in physiological parameters and adverse effects were considered.

\section{Data collection and analysis}

Data from the studies were extracted independently by two authors using standardised forms. Study quality was assessed. Dichotomous data were expressed as odds ratio $(\mathrm{OR})$ and a pooled $\mathrm{OR}$ was calculated using the random-effects model. 


\section{Main results}

Of 35 studies considered potentially relevant, 14 studies enrolling 1025 subjects met the entry criteria. Scopolamine was administered via transdermal patches, tablets or capsules, oral solutions or intravenously. Scopolamine was compared against placebo, calcium channel antagonists, antihistamine, methscopolamine or a combination of scopolamine and ephedrine. Studies were generally small in size and of varying quality.

Scopolamine was more effective than placebo in the prevention of symptoms. Comparisons between scopolamine and other agents were few and suggested that scopolamine was superior (versus methscopolamine) or equivalent (versus antihistamines) as a preventative agent. Evidence comparing scopolamine to cinnarizine or combinations of scopolamine and ephedrine is equivocal or minimal.

Although sample sizes were small, scopolamine was no more likely to induce drowsiness, blurring of vision or dizziness compared to other agents. Dry mouth was more likely with scopolamine than with methscopolamine or cinnarizine.

No studies were available relating to the therapeutic effectiveness of scopolamine in the management of established symptoms of motion sickness.

\section{Authors' conclusions}

The use of scopolamine versus placebo in preventing motion sickness has been shown to be effective. No conclusions can be made on the comparative effectiveness of scopolamine and other agents such as antihistamines and calcium channel antagonists. In addition, no randomised controlled trials were identified that examined the effectiveness of scopolamine in the treatment of established symptoms of motion sickness.

\section{PLAIN LANGUAGE SUMMARY}

\section{Scopolamine is effective for preventing motion sickness.}

This Cochrane review summarises evidence from 14 randomised controlled studies evaluating the effectiveness and safety of scopolamine for motion sickness. The results show that scopolamine was more effective than placebo and scopolamine-like derivatives in the prevention of nausea and vomiting associated with motion sickness. However, scopolamine was not shown to be superior to antihistamines and combinations of scopolamine and ephedrine. Scopolamine was less likely to cause drowsiness, blurred vision or dizziness when compared to these other agents. 


\section{B A C K G R O U N D}

\section{Description of the condition}

Motion sickness (or travel sickness) describes the discomfort felt by individuals caused by repetitive angular and linear acceleration and deceleration. The symptoms associated with motion sickness include nausea, vomiting, pallor, cold sweats, hypersalivation, hyperventilation and headaches. These symptoms often occur during travel in vehicles (e.g. cars, trains, airplanes, ships) or when in motion (e.g. fairground rides, swings). Motion is not a requirement for the disorder to manifest. Thus, one can experience the symptoms of motion sickness even when motionless, as when viewing movies shot on a shaky camera or when taking part in 'virtual reality' rides in amusement parks. An important aspect of the disorder is the propensity for the symptoms to resolve with continued exposure to stimuli, a characteristic called adaptation or habituation. Previous hypotheses about the development of motion sickness held that symptoms were due to either reduced cerebral blood flow or to motion of the viscera prompting stimulation of afferent nerves in abdominal organs (Oman 1990). The most widely held explanation for the cause of motion sickness is described by the sensory conflict hypothesis (Reason 1970; Reason 1975; Yardley 1992). Briefly, the hypothesis postulates that each person has an internal representation of bodily movement. This internal picture is continuously updated by information from sensory receptors such as the eyes, the vestibular system, and mechanoceptors in joints and muscles. Motion sickness develops when repeated and sustained mismatches occur between the information received from the sensory receptors and the expected internal model. It is claimed that adaptation is evidence of the central nervous system's gradual recognition that conflicting sensory inputs are being received. This leads to appropriate reductions in symptoms.

The incidence of motion sickness has been examined in diverse populations (Ungs 1988; Antuano 1989; Lawther 1988). Ungs 1988 found that $64.3 \%$ of 238 pilots undergoing flight simulator training reported at least one adverse symptom. Lawther's (1988) study on board passenger ferries also showed similar results with $7 \%$ of 20,029 individuals reporting bouts of vomiting. A positive diagnosis of motion sickness was further established for $64 \%$ of 45 military parachutists on their first jump by Antuano 1989 . However, estimates should be understood in the context of the sensory conflict hypothesis. Theoretically, all individuals may suffer from motion sickness symptoms when subject to the necessary stimulus. In this general sense, the incidence and the prevalence of the disorder is dependent on each person's susceptibility and capacity to adapt to the stimulus as much as it is to the nature of the stimulus itself. Of equal importance is the disabling nature of the disorder when afflicted individuals are unable to perform work-related tasks, although this aspect of the disorder has been studied less.

\section{Description of the intervention}

The prevention and control of motion sickness symptoms have involved the use of pharmacological interventions, behavioural therapy and complementary medicine with varying success. Scopolamine (hyoscine), an anticholinergic, is one of the most commonly used pharmacological agents for motion sickness. Other commonly used drugs include other anticholinergics (e.g. zamafenacin), antihistamines (e.g. meclozine, flunarizine), sympathomimetics and opioids. Visualisation and biofeedback are two behavioural therapies that have been examined. Complementary medical therapies that have been used include acupressure, acupuncture and herbal remedies.

\section{How the intervention might work}

Scopolamine is an alkaloid drug which is derived from Solanaceous plants, chiefly from henbane (Hyoscyamus niger). Its pharmacological properties arise through interference with the transmission of vestibular input to the central nervous system. This acts to inhibit the vomiting impulse normally activated by motion sickness. Scopolamine can be delivered through a variety of means, including intravenous injection, ingestion of tablets or liquid formulations, or topical application with adhesive transdermal patches. The duration of treatment effectiveness varies according to the means of administration. For example, transdermal patches may be effective for up to three days, whilst tablets may need to be taken every six hours for continued efficacy. Adult doses are typically 0.3 to $0.6 \mathrm{mg}$ daily, whilst smaller doses of approximately $0.006 \mathrm{mg} / \mathrm{kg}$ are administered to children.

Adverse effects experienced are typical of parasympathetic system depression and include drowsiness, dilated pupils, rapid heartbeat, and dry skin, mouth and respiratory passages. Overdose of scopolamine may cause symptoms of delirium, delusions, memory disturbances, paralysis and stupor. Withdrawal symptoms have also been noted after discontinuation following prolonged use and include dizziness, nausea, headache and vomiting.

\section{Why it is important to do this review}

To date, there have been no known systematic reviews of the effectiveness of scopolamine in preventing and controlling motion sickness.

\section{O B J E C T I VES}

The objective of this review was to assess the effectiveness of scopolamine versus no therapy, placebo, other drugs, behavioural and complementary therapy, or two or more of the above therapies in combination, for motion sickness in persons (both adults and children) without known vestibular, visual or central nervous system pathology. The review focused on the two broad areas of prevention and treatment. 


\section{METHODS}

\section{Criteria for considering studies for this review}

\section{Types of studies}

We included all parallel-arm, randomised controlled trials (RCTs) that focused on scopolamine versus no therapy, placebo, other drugs, behavioural and complementary therapy or two or more of the above therapies in combination.

\section{Types of participants}

We focused on participants with motion sickness and no known vestibular, visual or central nervous system pathology. Studies were included regardless of the method used to induce motion sickness.

\section{Types of interventions}

Treatments administered as a single-agent therapy for preventing and treating motion sickness were examined, regardless of route. If a second active ingredient was included during administration, only those studies that had a group concurrently on scopolamine alone were examined. Scopolamine was compared, where possible, to each of the following comparison therapies:

- no therapy

- placebo

- other drugs (anticholinergics, antihistamines, sympathomimetics, antiemetics, opioids)

- scopolamine plus another drug

- behavioural therapies (biofeedback, visualisation)

- complementary therapies (acupressure, acupuncture, herbal remedies)

- two or more of the above therapies in combination

Types of outcome measures

Studies were eligible for inclusion if they reported any of the following outcome measures.

\section{Primary outcomes}

Prevention of onset and treatment of clinically defined motion sickness - differences in frequency, duration and severity of symptoms

\section{Secondary outcomes}

- Task ability and psychological tests (tapping speed or the Burdon Wiersma test)

- Changes in physiological parameters (heart rate, nystagmus, vagal tone, electrogastrography)

- Adverse effects (dry mouth, drowsiness, visual disturbances)

\section{Search methods for identification of studies}

\section{Electronic searches}

We searched the Cochrane Ear, Nose and Throat Disorders Group Trials Register, the Cochrane Central Register of Controlled Trials
(The Cochrane Library, Issue 2, 2007), MEDLINE (1966 to May 2007), EMBASE (1974 to May 2007), CINAHL (1982 to May 2007), LILACS, $m$ RCT (metaRegister of Controlled Trials), National Research Register, KoreaMed, IndMed, PakMediNet, ISI Proceedings (Web of Knowledge), Cambridge Scientific Abstracts (Conference Proceedings Database) and ZETOC. The date of the last search was May 2007.

The search strategy for CENTRAL is shown in Appendix 1. In MEDLINE, this search strategy was combined with the Cochrane Highly Sensitive Search Strategy for retrieving randomised controlled trials described in the Cochrane Reviewers' Handbook ( Higgins 2006). No language restrictions were applied.

Records retrieved by the initial search were scanned by two reviewers (AS and JW) to identify trials that met the pre-defined inclusion criteria. Full-text articles were retrieved and reviewed by two reviewers (AS and JW) for the purpose of applying inclusion criteria independently. Reference lists of retrieved studies were examined for relevant articles. In all instances, differences of opinion were resolved by discussion.

\section{Data collection and analysis}

\section{Selection of studies}

Records retrieved by the initial search were scanned by AS and JW to exclude obviously irrelevant studies, then the same authors identified trials that may have met the inclusion criteria. Full-text articles were retrieved and reviewed for the purpose of applying inclusion criteria independently. In all instances, differences of opinion were resolved by discussion among the authors.

\section{Data extraction and management}

Data from the studies were extracted independently by two authors (AS and JW) using standardised forms developed for this review. Due to the length of time since publication for many of the included studies, the authors of primary studies were not contacted to provide information when missing or incomplete data were encountered. All differences were resolved by discussion among the review authors.

\section{Assessment of risk of bias in included studies}

Study quality was assessed using an adaptation of the method outlined in Schultz 1995. Results from the study quality are presented in a descriptive manner. The following characteristics were assessed:

\section{Adequacy of the randomisation process}

A: Adequate sequence generation is reported using random number tables, computer random number generator, coin tossing, or shuffling.

B: Did not specify one of the adequate reported methods in (A) but mentioned randomisation method.

C: Other methods of allocation that may not be random. 


\section{Adequacy of the allocation concealment process}

Trials were awarded the following grades for allocation concealment:

A: Adequate: a randomisation method described that would not allow an investigator/participant to know or influence an intervention group before an eligible participant entered the study, such as central randomisation; serially numbered, opaque, sealed envelopes.

B: Unclear: trial states that it is 'randomised', but no information on the method used is reported or a method is reported that was not clearly adequate.

C: Inadequate: inadequate method of randomisation used, such as alternate medical record numbers or unsealed envelopes; or any information in the study that indicated that investigators or participants could influence the intervention group.

\section{Potential for selection bias after allocation}

A: Yes - Specifically reported by authors that intention-to-treat was undertaken and this was confirmed on study assessment, or not stated but evident from study assessment that intention-to-treat was undertaken

B: Unclear - Reported, but unable to confirm on study assessment, or not reported and unable to confirm by study assessment.

C: No - Lack of intention-to-treat confirmed on study assessment (patients who were randomised were not included in the analysis because they did not receive the study intervention, they withdrew from the study or were not included because of protocol violation) regardless of whether intention-to-treat reported or not.

\section{Completeness of follow up}

Percentage of participants for whom data was complete at defined study end-point.

Level of masking (treatment provider, patient, outcome assessor):

A: Trials which report any blinding of either outcome assessor (most likely) or treatment provider or patient (less likely).

B: Blinding not undertaken.

C: Unclear whether any blinding was undertaken.

\section{Data synthesis}

We used Review Manager 4.2 for data analysis and quantitative data synthesis. For dichotomous data, we calculated individual and pooled statistics as relative risk (RR) with $95 \%$ confidence intervals $(95 \% \mathrm{CI})$. We gave consideration to the appropriateness of meta-analysis in the presence of significant clinical or statistical heterogeneity. We tested for heterogeneity using the $\mathrm{I}^{2}$ statistic and significant heterogeneity was assumed if the $\mathrm{I}^{2}$ was greater than $40 \%$ (i.e. more than $40 \%$ of the variability in outcome between trials could not be explained by sampling variation) (Higgins 2003). We used a fixed-effects model in the absence of statistical heterogeneity and a random-effects model if heterogeneity was likely.

\section{RE S U L T S}

\section{Description of studies}

See: Characteristics of included studies; Characteristics of excluded studies.

\section{Results of the search}

Thirty-three studies were considered potentially relevant. Of the 35 articles assessed in full text format, nine were excluded because of non-randomisation to treatment groups or failure to report on the method of allocation, ten were excluded because of design (e.g. crossover trials), one lacked an appropriate control group, one involved scopolamine only, one examined peripheral vestibular vertigo rather than motion sickness and one was awaiting translation. The remaining 14 randomised controlled trials formed the basis of this review.

\section{Included studies}

Fourteen randomised controlled trials, with a total of 1025 participants, compared preventative transdermal scopolamine with placebo, scopolamine derivatives, scopolamine combinations, antihistamines and calcium channel antagonists. Participants were predominantly young, healthy males, only three studies having recruited female participants (Dornhoffer 2004; Price 1981; Offenloch 1986) and three studies not specifying gender (Brand 1968; Hargreaves 1982; Tokola 1984). A large number of participants, with ages ranging from 16 to 55 years were naval personnel on training or service exercises. Most studies specifically recruited participants with a history of motion sickness.

Scopolamine was administered to participants in several ways, the most common being transdermal patches (Attias 1987; Becker 1984; How 1988; Offenloch 1986; Price 1981; van Marion 1985) and oral tablets or capsules (Brand 1968; Dornhoffer 2004; Hargreaves 1982; Laitinen 1981; Nuotto 1983; Pingree 1994; Tokola 1984). Intravenous scopolamine was tested in one study ( Nuotto 1983) and an oral, water-based solution was used in another (Uijdehaage 1993).

The studies compared the efficacy of scopolamine for preventing or treating motion sickness with either placebo (Attias 1987; How 1988; Laitinen 1981; Price 1981; Tokola 1984; Uijdehaage 1993; van Marion 1985), calcium channel antagonists (Hargreaves 1982; Pingree 1994), the antihistamines meclozine (Becker 1984) and dimenhydrinate (Offenloch 1986; Price 1981), methscopolamine (Uijdehaage 1993) or a combination of scopolamine with ephedrine, cyclizine or placebo (Brand 1968; Laitinen 1981; Nuotto 1983; Tokola 1984 ). One study (Dornhoffer 2004) compared scopolamine to the benzodiazepine derivative, lorazepam, and the antihistamine, meclozine. No studies were found comparing scopolamine with behavioural or complementary therapies. Motion sickness was either purposely induced or occurred due to natural circumstances. Sailing was the most common method of inducing sickness, with trip lengths ranging from seven hours to two weeks. Two studies used simulators to induce sickness and one study tested treatment effectiveness during a one-hour flight. 


\section{Risk of bias in included studies}

Results of the quality assessment are provided in the 'Characteristics of included studies' table. The methodological quality of the trials was assessed independently by two authors and was described descriptively (AS and JW). The included studies were of varying methodological quality.

All studies were reported as randomised but only one (Laitinen 1981) described generation of the allocation sequence. Allocation was reported as being adequately concealed in three studies ( Becker 1984; Nuotto 1983; Offenloch 1986) and was unclear in the remaining 11 studies. Although 12 of the studies were doubleblinded, two studies (Attias 1987; Hargreaves 1982) failed to report on its masking. All studies failed to report on losses to follow up and no intention-to-treat analysis was undertaken. No attempt was made to contact authors to clarify this concern.

Study populations were generally small in size and mostly male. Most studies reported clear, though sometimes brief, inclusion and exclusion criteria.

\section{Effects of interventions}

The results are presented in four sections reflecting the type of outcome measure identified as being of interest: prevention of sickness symptoms (nausea), prevention of vomiting, task ability and psychological tests, and adverse events. No randomised controlled trials were identified examining the effectiveness of scopolamine in the treatment of established symptoms of motion sickness.

\section{Primary outcomes}

\section{Prevention of sickness symptoms (nausea)}

Five studies (Attias 1987; Laitinen 1981; Price 1981; Tokola 1984; Uijdehaage 1993) showed a superior effect of transdermal scopolamine over placebo for preventing sickness symptoms. Relative Risk (RR) was 0.47 (95\% confidence interval (CI) 0.31 to 0.71 ). A further three studies (Dornhoffer 2004; How 1988; van Marion 1985) also suggested a superior effect of scopolamine over placebo for preventing or delaying motion sickness symptoms, but these could not be pooled due to the absence of data and poor or significant variations in reporting.

Uijdehaage 1993 found transdermal scopolamine was superior in preventing sickness when compared to methscopolamine (RR $0.3395 \%$ CI 0.09 to 1.19 ). When compared to the antihistamine, meclozine, scopolamine showed a decrease in the mean motion sickness score (motion sickness score: $89 \%$ with scopolamine versus 59\% with meclozine) (Becker 1984), and delayed the onset of symptoms for longer than meclozine (mean time and percentage increase from baseline: 4.32 minutes [32.47\%] with scopolamine versus 0.58 seconds [8.66\%] with mecolazine (Dornhoffer 2004). Transdermal scopolamine was equivalent to other antihistamines such as promethazine (Dornhoffer 2004) and dimenhydrinate ( Offenloch 1986) in preventing motion sickness.

Studies comparing the effectiveness of scopolamine with cinnarizine produced mixed results. One study (Pingree 1994) found scopolamine superior to cinnarizine in preventing seasickness symptoms amongst 179 participants serving on two warships for periods of up to 60 and 40 hours, respectively. A higher prevalence of seasickness was found in the cinnarizine group (range 10\% to $60 \%$ ) than in the scopolamine group (range $10 \%$ to $35 \%$ ). A second trial enrolling 39 participants (Hargreaves 1982) showed scopolamine to be less likely to prevent symptoms of seasickness than cinnarizine. Eighty-one percent of participants administered scopolamine $(\mathrm{n}=21)$ versus $89 \%$ of those administered cinnarizine $(n=18)$ reported that the treatment helped either "a little" or "very much" in preventing symptoms.

When scopolamine alone or in combination with ephedrine was studied (Laitinen 1981; Tokola 1984), the meta-analysis showed no statistically significant results, although fewer participants treated with scopolamine alone reported symptoms. The pooled RR was 0.70 (95\% CI 0.39 to 1.26). Scopolamine was more effective at delaying the onset of motion sickness than lorazepam which was found to hasten the onset of symptoms: mean time and percentage change from baseline: 4.32 minutes [32.47\%] with scopolamine compared with -1.35 minutes [ $-1.65 \%$ ] with lorazepam ( Dornhoffer 2004).

\section{Prevention of vomiting}

Two studies (Laitinen 1981; Tokola 1984) compared the effectiveness of scopolamine with the combination of scopolamine and ephedrine. Only five cases of vomiting were reported overall. The pooled RR was 1.31 (95\% CI 0.28 to 6.00$)$. A third study by van Marion 1985 found no significant difference in the prevention of vomiting between those taking scopolamine and placebo (reported as a percentage of subjects: $27 \%$ taking scopolamine versus $30 \%$ taking placebo) at day one. Similar figures were also reported for days two, three and four.

\section{Secondary outcomes}

\section{Task ability and psychological tests}

Four studies (Brand 1968; Nuotto 1983; Pingree 1994, van Marion 1985) compared task ability and psychological testing. These studies could not be pooled due to the differences in outcomes. Participants administered either scopolamine or placebo during calculation and an audio-visual checking test showed no marked difference in performance (Brand 1968). This lack of effect was observed in a second study (Nuotto 1983) in which no significant memory impairment was shown for both reverse order repetition tests and paired association learning tasks in participants administered scopolamine compared with those administered placebo. There were no differences between the performance in Tapping speed, Burdon Wiersma test or Digit Symbol Test. Pingree 1994 assessed performance impairment in participants treated with either scopolamine or cinnarizine whilst serving on two separate warships. On the first ship, the two groups reported similar impairment levels of $10 \%$ to $20 \%$. On the second ship, a higher level of performance impairment was reported by participants treated with scopolamine (up to 40\%) compared with 
cinnarizine (less than 10\%). In the last study, van Marion 1985 assessed the processing of information by using the Burdon Wiersma test which, performed before application of the patch and 24 hours thereafter, revealed no difference between the scopolamine and placebo group. At the second testing, all participants performed better, probably because of the known learning effect with information and task related activities.

\section{Adverse events}

\section{Drowsiness}

Two studies (Laitinen 1981; Uijdehaage 1993) compared scopolamine with placebo for the experience of drowsiness. With 60 individuals participating, no significant difference between the two treatments was noted despite a trend toward greater drowsiness amongst participants using scopolamine (pooled RR 1.42; 95\% CI 0.79 to 2.56). A further two studies (Price 1981; van Marion 1985) found no statistically significant difference in the experience of drowsiness amongst participants treated with either scopolamine or placebo, although the data could not be pooled due to poor reporting. One study (Uijdehaage 1993) comparing scopolamine to methscopolamine found no significant difference in the prevalence of drowsiness amongst its participants.

Drowsiness was also measured in two studies that compared scopolamine with cinnarizine. The first study (Hargreaves 1982) found scopolamine was more likely to induce drowsiness (3/21 participants) compared to those in the cinnarizine group (0/18 participants). The second study (Pingree 1994) found no statistically significant differences between the two treatment groups. However, the study (Pingree 1994) reported a higher prevalence of drowsiness amongst participants treated with scopolamine aboard one of two ships used. It appeared that drowsiness levels were higher in calmer ship conditions, with nearly $60 \%$ of scopolamine treated participants experiencing drowsiness at times of minimal ship motion compared with $35 \%$ of participants treated with cinnarizine.

\section{Blurred vision}

Two studies found no significant difference when comparing the incidence of blurred vision with scopolamine and placebo (RR 2.73 95\% CI 0.89 to 8.37; P = 0.08) (van Marion 1985; Uijdehaage 1993). A third study by Price 1981 reported no differences in the participants' vision when treated with either scopolamine or placebo (results not presented graphically; P value not reported). . When comparing the symptoms of blurred vision in those taking scopolamine versus cinnarizine, Pingree 1994 reported a significantly greater prevalence of visual disturbances amongst participants treated with scopolamine than those treated with cinnarizine.

\section{Dry mouth}

Three studies (Price 1981; van Marion 1985; Uijdehaage 1993) found that the symptom of dry mouth was apparent in those treated with scopolamine rather than placebo. In the first study ( Uijdehaage 1993), 7/20 (35\%) participants reported dry mouth symptoms compared to $1 / 20(5 \%)$ in the placebo arm. When treated with methscopolamine, the same study found a greater prevalence of dry mouth symptoms amongst participants treated with scopolamine (35\%) than methscopolamine (10\%).

In the study by van Marion 1985, the prevalence of dry mouth on days three and four was significantly higher amongst participants administered scopolamine compared to placebo (reported as a percentage of subjects: $34 \%$ taking scopolamine versus $7 \%$ taking placebo at day three, $\mathrm{P}<0.01$; and $31 \%$ taking scopolamine versus $9 \%$ taking placebo at day four, $\mathrm{P}<0.05$ ). However, there was no difference between groups experiencing dry mouth at days one and two (reported as a percentage of subjects: $26 \%$ taking scopolamine versus $23 \%$ taking placebo at day one and $36 \%$ taking scopolamine versus $25 \%$ taking placebo at day two). This may have been because the symptom of dry mouth may have accompanied nausea and motion sickness experienced early in the voyage.

A study (Pingree 1994) comparing scopolamine with cinnarizine reported a significantly greater prevalence of dry mouth in those treated with scopolamine rather than cinnarizine. Scopolamine was also more likely to cause symptoms of dry mouth for those treated with dimenhydrinate (Offenloch 1986). Five (50\%) participants treated with scopolamine reported mild to moderate dry mouth symptoms, whereas no such symptoms were reported by participants treated with dimenhydrinate.

\section{Dizziness}

Two studies (van Marion 1985; Uijdehaage 1993) compared scopolamine with other treatments for the adverse symptom of dizziness. In the first study, van Marion 1985 found no difference with the onset of dizziness between scopolamine and the placebo group (reported as a percentage of subjects: $15 \%$ taking scopolamine versus $26 \%$ taking placebo at day one and $27 \%$ taking scopolamine versus $22 \%$ taking placebo at day two). In the second study by (Uijdehaage 1993), 10\% ( $\mathrm{n}=20)$ of scopolamine treated participants reported dizziness compared with no participants treated with either placebo or methscopolamine alone.

\section{DISCUSSION}

There is evidence to support the use of scopolamine versus placebo in the prevention of sickness symptoms such as nausea and vomiting. Scopolamine in conjunction with ephedrine was not significantly different, although fewer participants treated with scopolamine alone reported symptoms. Many of the other trials using other agents were far less than conclusive.

Trials using antihistamines as a comparator showed mixed results for decreasing motion sickness with one study highlighting scopolamine's superiority (Becker 1984) and the other claiming equal efficacy (Offenloch 1986). Both studies included a small number of participants, indicating the likelihood of an underpowered 
study. Neither study design nor outcome definitions could have explained this heterogeneity. The variety of histamine antagonists used was the most plausible explanation, but could not be confirmed given the different types of antihistamines used within the studies and the lack of consistent outcome reporting by type of antihistamine exposure.

Two of the studies that used cinnarizine as comparator could not be pooled thus providing only a descriptive analysis of their effectiveness. Cinnarizine was far less effective than scopolamine but, in an alternative trial by Hargreaves, the two drugs were reported as being "statistically indistinguishable" in preventing nausea and vomiting symptoms. The reported differences could not be explained, but perhaps the aggressive motion (Pingree 1994) interacted with the drug action to result in the superior efficacy of scopolamine with an associated comparative reduction in side effects as motion severity increased.

Adverse effects in the form of level of drowsiness, blurred vision, dry mouth and dizziness were reported amongst the studies. A trend towards increased drowsiness was noted when scopolamine was compared to placebo, scopolamine derivatives and calcium channel antagonists. The dry mouth and visual disturbances were seen as being well-documented peripheral side effects of anticholinergic drugs rather than a manifestation of motion sickness. Conversely, participants might have had difficulty in distinguishing between the symptoms observed during motion sickness and those that were included in the category of adverse effects. In the poorly defined nausegonic conditions that defined some studies ( Hargreaves 1982), cinnarizine had less profound side effects and was better tolerated than scopolamine.

It is important to note that the method of scopolamine delivery varied across the studies. There were three possible delivery modes tested: oral (tablets or liquid), intravenous and transdermal, with half of the studies using transdermal scopolamine systems and the remaining testing oral preparations with one testing both oral and intravenous routes. The transdermal patch was most likely used to minimise the relatively high incidence of adverse effects seen with other routes of administration. More importantly, the main pharmokinetic difference between these delivery modes is the time taken for plasma concentrations to reach therapeutic levels with intravenous and oral routes taking one to two hours to take effect for a period of six hours while the transdermal routes take approximately eight hours to become therapeutically effective for over 72 hours. Additionally, the dosage of oral scopolamine administered to subjects ranged from 0.1 to $0.9 \mathrm{mg}$ which would mean that plasma concentration levels of scopolamine would have differed between these studies.

Although scopolamine was seen to be effective for the prevention of sickness symptoms, methodological quality issues and small sample sizes may have limited the validity of these findings. The largest study included 179 participants and six of the 12 studies included
50 participants or fewer. No studies investigated the effectiveness or tolerance of scopolamine in children, and only two studies reported recruiting female participants. In the studies where scopolamine was found to be no more effective than a comparator (e.g. antihistamines), lack of sufficient power may have resulted in an erroneous conclusion. Furthermore, the quality of the trials varied. There were many opportunities for systematic bias as only a minority reported on an appropriate method of randomisation or on concealment of allocation, although incomplete reporting did not necessarily mean that the effectiveness of scopolamine was in doubt. Despite the potential biases that would most likely work against the intervention arm, the overall findings were that scopolamine was effective as a means of preventing motion sickness.

It appears that research into the effectiveness of scopolamine for treating or preventing motion sickness has declined since its peak during the 1980s. Only three of the included studies were conducted in the past 15 years. Similarly, only five of the 20 excluded studies were conducted in this time period. Examining the included studies in chronological order did not reveal any consistent pattern of dosage, method or comparators, and the general methodological quality did not improve over time.

\section{AUTHORS' CONCLUSIONS}

\section{Implications for practice}

The use of scopolamine versus placebo in preventing motion sickness has been shown to be effective. No conclusions or recommendations can be made on the comparative effectiveness of scopolamine and other agents such as antihistamines and calcium channel antagonists. In addition, no randomised controlled trials were identified that examined the effectiveness of scopolamine in the treatment of established symptoms of motion sickness.

\section{Implications for research}

The lack of high quality evidence showing the effectiveness and safety of scopolamine for preventing or treating motion sickness in women and children indicates a gap that should be a priority for future research studies. Well-designed randomised controlled trials with sufficient power are also needed to test the effectiveness of scopolamine compared to other pharmaceutical therapies as well as behavioural and complementary therapies. The synthesis of future trials would be assisted if standardised outcome, motion condition and treatment regimes and / or dosages were used. All trials should also include a measure of adverse outcomes so that more evidence is available to compare the safety of scopolamine with other treatments.

\section{ACKNOWLEDGEMENTS}


We wish to thank the previous co-authors, Elmer Villaneuva and Vivienne Bernath, with the input into the development of this review. The clinical question arose from a project funded by the General Practice Evaluation Program (Del Mar 2001).

\section{RE F E R E N C E S}

\section{References to studies included in this review}

Attias 1987 \{published data only\}

Attias J, Gordon C, Ribak J, Binah O, Rolnick A. Efficacy of transdermal scoplamine against seasickness: a 3-day study at sea. Aviation, Space and Environmental Medicine 1987;58:60-2.

Becker 1984 \{published data only\}

Becker G, Goossens H, Seemann K, Souchon F, Weitz Th. Prevention of motion sickness with a transdermal therapeutic system containing scopolamine. A randomized, comparative double-blind study in the German Federal Navy [Kinetoseprophylaxe mit TTSScopolamin. Une randomisierte, vergleichende Doppelblinstudie bei der Bundesmarine]. Deutsche Medizinische Wochenschrift 1984; 109:1881-5.

Brand 1968 \{published data only\}

Brand JJ, Colquhoun WP, Perry WLM. Side-effects of 1-hyoscine and cyclizine studies by objective tests. Aerospace Medicine 1968;39: 999-1002.

Dornhoffer 2004 \{published data only\}

Dornhoffer J, Chelonis JJ, Blake D. Stimulation of the semicircular canals via the rotary chair as a means to test pharmacologic countermeasures for space motion sickness. Otology and Neurotology 2004; 25:740-745.

Hargreaves 1982 \{published data only\}

Hargreaves J. The prophylaxis of seasickness. A comparison of cinnarizine with hyoscine. New Zealand Medical Journal 1982;226: $160-1$.

How 1988 \{published data only\}

How J, Lee PS, Seet LC, Tan PK. The Republic of Singapore Navy's Scopoderm TTS Study: results after 2,200 man-days at sea. Aviation, Space and Environmental Medicine 1988;59:646-50.

Laitinen 1981 \{published data only\}

Laitinen LA, Tokola O, Gothoni G, Vapaatalo H. Scopolamine alone or combined with ephedrine in seasickness: a double blind, placebocontrolled study. Aviation, Space and Environmental Medicine 1981; 52:6-10.

Nuotto 1983 \{published data only\}

Nuotto E. Psychomotor, physiological and cognitive effects of scopolamine and ephedrine in healthy man. European Journal of Clinical Pharmacology 1983;24:603-9.

Offenloch 1986 \{published data only\}

Offenloch K. Comparative in-flight study of a scopolamine containing membrane plaster versus dimenhydrinate under defined acceleration conditions [Vergleichende Inflight-Untersuchung eines Scopolamin-haltigen Membranpflasters versus Dimenhydrinat unter definierten Beschleunigungsreizen]. Aezneimittelforschung 1986;36:1401-6.
Pingree 1994 \{published data only\}

Pingree BJW, Pethybridge RJ. A comparison of the efficacy of cinnarizine with scopolamine in the treatment of seasickness. Aviation, Space and Environmental Medicine 1994;65:597-605.

Price 1981 \{published data only\} Price NM, Schmitt LG, McGuire J, Shaw JE, Trobough G. Transdermal scopolamine in the prevention of motion sickness at sea. Clinical Pharmacology and Therapeutics 1981;29:414-9.

Tokola 1984 \{published data only\}

Tokola O, Laitinen LA, Aho J, Gothoni G, Vapaatalo H. Drug treatment of motion sickness: scopolamine alone and combined with ephedrine in real and simulated situations. Aviation, Space, and Environmental Medicine 1984;55:636-41.

Uijdehaage 1993 \{published data only\} Uijdehaage SHJ, Stern RM, Koch KL. Effects of scopolamine on autonomic profiles underlying motion sicknes susceptibility. Aviation, Space and Environmental Medicine 1993;64:1-8.

van Marion 1985 \{published data only\} van Marion WF, Bongaerts MCM, Christiaanse JC, Hofkamp HG, van Ouwerkerk W. Influence of transdermal scopolamine on motion sickness during 7 days' exposure to heavy seas. Clinical Pharmacology and Therapeutics 1985;38:301-305.

\section{References to studies excluded from this review}

Aizikov 1985 \{published data only\}

Aizikov GS. Effect of experimental motion sickness on prostrotatory nystagmus and the illusion of the counterrotation. Kosmicheskaia Biologiia i Aviakosmicheskaia Meditsina 1985;19:89-91.

Bodo 1982 \{published data only\} Bodo D, Kotovskaia AR, Galle RR, Gavrilova LN, Gusakova GA. Effectiveness of the preparation Gavinton in preventing motion sickness. Kosmicheskaia Biologiia i Aviakosmicheskaia Meditsina 1982;16: 49-51.

Brand 1967 \{published data only\} Brand JJ, Colquhoun WP, Gould AH, Perry WLM. Hyoscine and cyclizine as motion sickness remedies. British Journal of Pharmacology and Chemotherapy 1967;30:463-469.

Brand 1969 \{published data only\}

Brand JJ. A comparison of the effects of hyoscine and amylobarbitone sodium on measurements of post-rotational turning sensation and nystagmus. Acta oto-laryngologica 1969;68:427-434.

\section{Cipriani 1987 \{published data only\}}

Cipriani G, Perazzetti F, Di Luzio Paparetti U, Cipriani GC. A double blind study using transdermal scopolamine for peripheral vestibular 
vertigo [Studio clinico in doppio cieco sull'utilizzazione della scopolamina per via transdermica nella vertigine vestibolare periferica]. Valsalva 1987;63:58-62

Cirillo 1986 \{published data only\}

Cirillo B, Sabato F, Vigliano R. Seasickness prevention and therapy [La naupatia: prevenzione e terapia]. Annalis di Medicina Navale 1986;91:161-70.

Estrada 2007 \{published data only\}

Estrada A, LeDuc PA, Curry IP, Phelps SE, Fuller DR. Airsickness prevention in helicopter passengers. Aviation Space and Environmental Medicine 2007;78(4):408-13.

Galle 1988 \{published data only\} Galle RR. Evaluation of the effectiveness of drugs for prevention of motion sickness. Kosmicheskaia Biologiia i Aviakosmicheskaia Meditsina 1988;22:90-4.

Glaznikov 1992 \{published data only\} Glaznikov LA, Yanov Yu K, Butko Yu D, Shutov EB. On pharmacoprophylaxis of motion disease syndrome occurring. Zhurnal Ushnykh, Nosovykh i Gorlouykh Boleznei 1992;52:31-7.

Gordon 2001 \{published data only\}

Gordon CR, Gonen A, Nachum Z, Doweck I, Spitzer O, Shupak A. The effects of dimenhydrinate, cinnarazine and transdermal scopolamine on performance. Journal of Psychopharmacology 2001;15: $167-72$.

Gowans 2000 \{published data only\}

* Gowans J, Matheson A, Darlington CL, Smith PF. The effects of scopolamine and cyclizine on visual-vestibular interaction in humans. Journal of Vestibular Research 2000;10:87-92.

Hordinsky 1982 \{published data only\}

Hordinsky JR, Schwartz E, Beier J, Martin J, Aust G. Relative efficacy of the proposed space shuttle antimotion sickness medications. Acta Astronautica 1982;9:375-383.

Howland 2006 \{published data only\}

Howland J. Effects of Transdermal Scopolamine on Occupational Performance. www.clinicaltrials.gov 2006. [: NCT00374478]

Ilyina 1986 \{published data only\}

Ilyina SL, Sabaev VV, Shashkov VS, Karsanova SK. The effect of pharmacological agents preventing the 'motion sickness syndrome' on the cardiovascular system in modelling the early period of adaption to weightlessness. Farmakologiya i Toksikologiya 1986;49:90-5.

Klocker 2001 \{published data only\}

${ }^{*}$ Klocker N, Hanschke W, Toussaint S, Verse T. Scopolamine nasal spray in motion sickness: a randomised, controlled, and crossover study for the comparison of two scopolamine nasal sprays with oral dimenhydrinate and placebo. European Journal of Pharmaceutical Sciences 2001;13:227-32.

Norfleet 1992 \{published data only\} Norfleet WT, Degioanni JJ, Calkins DS, Reschke MF, Bungo MW, Kutyna FA, Homick JL. Treatment of motion sickness in parabolic flight with buccal scopolamine. Aviation, Space and Environmental Medicine 1992;63:46-51.

Pyyko 1984 \{published data only\}

* Pyykko I, Padoan S, Schalen L, Lyttkens L, Magnusson M, Henriksson NG. The effects of TTS-Scopolamine, dimenhydrinate, li- docaine, and tocainide on motion sickness, vertigo, and nystagmus. Aviation, Space and Environmental Medicine 1985;56:777-82.

Pyykko I, Schalen L, Jantti V. Transdermally administered scopolamine vs. dimenhydrinate. I. Effect on nausea and vertigo in experimentally induced motion sickness. Acta Otolaryngol (Stockholm) 1985;99:588-96.

Pyykko I, Schalen L, Jantti V, Magnusson M. A reduction of vestibulo-visual integration during transdermally administered scopolamine and dimenhydrinate. Acta Otolaryngolica (Stockholm) 1984;406(Suppl):167-73.

Pyykko I, Schalen L, Matsuoka I. Transdermally administered scopolamine vs. dimenhydrinate. II. Effect on the different types of nystagmus. Acta Otolaryngol (Stockholm) 1985;99:597-604.

Sabato 1987 \{published data only\}

Sabato F, Vigliano R, Cirillo V. Treatment of motion sickness with scopolamine by the transdermal route [Trattamento della naupatia mediante scopolamina somministrata per via transdermica]. Annali di Medicina Navale 1987;92:111-6.

Vigliano 1986 \{published data only\}

Vigliano R, Cirillo V, Sabato F, Cattoni M. Seasickness prevention using scopolamine (TCS mode), and placebo [Trattamento preventivo della naupatia con scopolamina per via transcutanea (TTS), dimenidrinato e placebo]. Annali di Medicina Navale 1986;91:15360.

Vigliano 1987 \{published data only\}

Vigliano R, Cirillo V, Sabato F, Cattoni M. Prevention of sea sickness with transdermal scopolamine, dimenhydrinate and a placebo. Gazzetta Medica Italiana Archivio Per Le Scienze Mediche 1987;146: $391-4$.

\section{Wang 1990 \{published data only\}}

Wang E. Transdermal therapeutic system of (TTS-S) in the prevention of sea sickness and its mechanism of action. Zhonghua Er Bi Yan Hou Ke Za Zhi 1990;25:299-302, 319.

Wolf 1987 \{published data only\}

Wolf M, Kronenberg J, Leventon G. Comparison of transdermal scopolamine and dimenhydrinate in acute vestibular disease. Harefua 1987;113:65-66.

\section{Additional references}

Antuano 1989

Antuano MJ, Hernandez JM. Incidence of airsickness among military parachutists. Aviation, Space and Environmental Medicine 1989;60: $792-7$.

Del Mar 2001

Del Mar CB, Silagy CA, Glasziou PP, Weller D, Spinks A, Bernath V, Anderson JN, Hilton DJ, Sanders SL. Feasibility of an evidencebased literature search service for general practitioners. The Medical Journal of Australia 2001;175:134-7.

\section{Higgins 2003}

Higgins JPT, Thompson SG, Deeks JJ, Altman DG. Measuring inconsistency in meta-analyses. British Medical Journal 2003;327:556560.

\section{Higgins 2006}

Higgins JPT, Green S, editors. Cochrane Handbook for Systematic Reviews of Interventions 4.2.6 [updated September 2006]. The Cochrane Library 2006, issue 4. 


\section{Lawther 1988}

Lawther A, Griffin MJ. A survey of the occurrence of motion sickness amongst passengers at sea. Aviation, Space and Environmental Medicine 1988;59:399-406.

Oman 1990

Oman CM. Motion sickness: a synthesis and evaluation of the sensory conflict theory. Canadian Journal of Physiology and Pharmacology 1990;68:294-303.

\section{Reason 1970}

Reason JT. Motion sickness: a special case of sensory rearrangement. Advancement of Science 1970;26:386-93.

Reason 1975

Reason JT, Brand JJ. Motion Sickness. London: Academic Press, 1975.

\section{Schultz 1995}

Schultz KF, Chalmers I, Hayes RJ, Altman DG. Empirical evidence of bias. Dimensions of methodological quality associated with estimates of treatment effects in controlled trials. JAMA 1995;273:408-12.

\section{Ungs 1988}

Ungs TJ. Simulator induced syndrome in Coast Guard aviators. Aviation, Space and Environmental Medicine 1988;59:267-72.

\section{Yardley 1992}

Yardley L. Motion sickness and perception: a reappraisal of the sensory conflict approach. British Journal of Psychology 1992;83(4):44971.

* Indicates the major publication for the study

\section{CHARACTERISTICSOFSTUDIES}

\section{Characteristics of included studies [ordered by study ID]}

\section{Attias 1987}

Methods Randomised controlled trial comparing adverse effects and efficacy of transdermal scopolamine with placebo for preventing seasickness.

Participants 38 male volunteers aged $20-25$ years.

Interventions

Transdermal scopolamine or identical placebo patches applied prior to a three day cruise. No dosage information was provided.

Outcomes Subjective ratings of seasickness and adverse effects of treatment.

Notes

All participants were disallowed drugs or alcohol during the study.

Schulz rating: randomisation B; allocation concealment B; selection bias B; blinding C. 
Attias 1987 (Continued)

\section{Risk of bias}

\begin{tabular}{|c|c|c|}
\hline Item & Authors' judgement & Description \\
\hline Allocation concealment? & Unclear & B - Unclear \\
\hline
\end{tabular}

Becker 1984

\begin{tabular}{|c|c|c|}
\hline Methods & \multicolumn{2}{|c|}{$\begin{array}{l}\text { Randomised, parallel-arm trial comparing adverse effects and efficacy of transdermal scopolamine with } \\
\text { oral meclazine for preventing motion sickness in an artificial sea voyage. }\end{array}$} \\
\hline Participants & \multicolumn{2}{|c|}{$\begin{array}{l}46 \text { healthy, male marines aged } 18 \text { to } 27 \text { years. } 19 \text { displayed susceptibility to motion sickness in a pre- } \\
\text { experiment. }\end{array}$} \\
\hline Interventions & \multicolumn{2}{|c|}{ Transdermal scopolamine or oral meclozine tablets taken prior to an artificial sea voyage. } \\
\hline Outcomes & \multicolumn{2}{|c|}{ Motion-sickness score. Digestibility of treatment. } \\
\hline Notes & \multicolumn{2}{|c|}{ Schulz rating: randomisation $\mathrm{B}$; allocation concealment $\mathrm{A}$; selection bias $\mathrm{B}$; blinding $\mathrm{A}$. } \\
\hline \multicolumn{3}{|l|}{ Risk of bias } \\
\hline Item & Authors' judgement & Description \\
\hline Allocation concealment? & Yes & A - Adequate \\
\hline
\end{tabular}

\section{Brand 1968}

\begin{tabular}{l|l} 
Methods & $\begin{array}{l}\text { Randomised, parallel-arm, controlled trial comparing psycho-physiological effects of scopolamine, cy- } \\
\text { clizine and placebo in the prevention of motion sickness. }\end{array}$ \\
\hline Participants & 120 sailors. No information was provided on age or gender. \\
\hline $\begin{array}{l}\text { Interventions } \\
\text { Oral doses of placebo, scopolamine }(0.1 \mathrm{mg}, 0.42 \mathrm{mg}, 0.7 \mathrm{mg}) \text { or cyclizine }(15 \mathrm{mg} \text { or } 100 \mathrm{mg}) \text { administered } \\
\text { prior to various tests. }\end{array}$ \\
\hline Outcomes & Objective measurements of salivation, pulse rate, power of accomodation and mental performance. \\
\hline Notes & Schulz rating: randomisation B; allocation concealment B; selection bias B; blinding A.
\end{tabular}

\section{Risk of bias}

Item Authors' judgement Description




\section{Brand 1968 (Continued)}

Allocation concealment? Unclear B - Unclear

\section{Dornhoffer 2004}

\begin{tabular}{|c|c|c|}
\hline Methods & \multicolumn{2}{|c|}{$\begin{array}{l}\text { Randomised, controlled trial comparing the efficacy of scopolamine, lorazepam, meclizine, promethazine } \\
\text { and placebo for protecting against motion sickness. }\end{array}$} \\
\hline Participants & \multicolumn{2}{|c|}{$\begin{array}{l}75 \text { healthy male and female volunteers aged } 18 \text { - } 44 \text { years, with no neurologic or psychiatric disorders and } \\
\text { no known allergies or previous adverse drug reactions. }\end{array}$} \\
\hline Interventions & \multicolumn{2}{|c|}{$\begin{array}{l}\text { Scopolamine }(0.4 \mathrm{mg}) \text {, lorazepam }(1 \mathrm{mg}) \text {, meclizine }(25 \mathrm{mg}) \text {, promethazine }(25 \mathrm{mg}) \text { or placebo adminis- } \\
\text { tered } 45 \text { minutes prior to blindfolding and chair rotation. Subjects were required to perform head move- } \\
\text { ments during rotation. }\end{array}$} \\
\hline Outcomes & \multicolumn{2}{|c|}{$\begin{array}{l}\text { Measurement of rotation duration until subject requested termination due to motion sickness symptoms, } \\
\text { could no longer perform head movements or maximum rotational velocity had been tolerated. }\end{array}$} \\
\hline Notes & \multicolumn{2}{|c|}{$\begin{array}{l}\text { Subjects were determined to be free of all medication and alcoholic substances } 72 \text { hours prior and at time } \\
\text { of testing. } \\
\text { Schulz rating: randomisation B; allocation concealment B; selection bias B; blinding A. }\end{array}$} \\
\hline \multicolumn{3}{|l|}{ Risk of bias } \\
\hline Item & Authors' judgement & Description \\
\hline Allocation concealment? & Unclear & D - Not used \\
\hline
\end{tabular}

\section{Hargreaves 1982}

\begin{tabular}{l|l}
\hline Methods & $\begin{array}{l}\text { Randomised, parallel-arm trial comparing the efficacy of scopolamine with cinnarizine for preventing sea } \\
\text { sickness. }\end{array}$ \\
\hline Participants & $\begin{array}{l}39 \text { volunteers from the Ocean Youth Club with known susceptibility to seasickness. No information was } \\
\text { provided on gender. }\end{array}$ \\
\hline Interventions & $\begin{array}{l}\text { Either two } 15 \mathrm{mg} \text { Cinnarizine tablets or one } 0.3 \mathrm{mg} \text { hyoscine tablet taken one to two hours prior to sailing } \\
\text { and thereafter every six to eight hours. }\end{array}$ \\
\hline Outcomes & Subjective reporting of efficacy of treatment (not at all; a little or very much) and drowsiness. \\
\hline Notes & Schulz rating: randomisation B; allocation concealment B; selection bias B; blinding C \\
\hline
\end{tabular}

\section{Risk of bias}


Hargreaves 1982 (Continued)

\begin{tabular}{l|ll}
\hline Item & Authors' judgement & Description \\
\hline Allocation concealment? & Unclear & B - Unclear \\
\hline
\end{tabular}

How 1988

\begin{tabular}{|c|c|c|}
\hline Methods & \multicolumn{2}{|c|}{$\begin{array}{l}\text { Randomised, controlled trial comparing efficacy of transdermal scopolamine with placebo for preventing } \\
\text { seasickness in both experienced and inexperienced sailors. }\end{array}$} \\
\hline Participants & \multicolumn{2}{|c|}{$\begin{array}{l}122 \text { officers and naval men who were either experienced }(<1 \text { year in navy, } n=59) \text { or inexperienced }(<1 \\
\text { year in navy, } n=63) \text {. Participant ages ranged from } 19 \text { to } 45 \text { years. }\end{array}$} \\
\hline Interventions & \multicolumn{2}{|c|}{$\begin{array}{l}\text { Transdermal Scopaderm TTS ( } 1.5 \mathrm{mg} \text { scopolamine) or identical placebo patches applied } 4 \text { hours prior to } \\
\text { sailing and then replaced every third day during sea voyage. }\end{array}$} \\
\hline Outcomes & \multicolumn{2}{|c|}{$\begin{array}{l}\text { Subjective analogue scale measurement of degree of seasickness experienced during previous } 24 \mathrm{~h} \text { at } 8 \mathrm{am} \\
\text { every day. }\end{array}$} \\
\hline Notes & \multicolumn{2}{|c|}{$\begin{array}{l}\text { No restrictions of food, water or other medications were imposed. } \\
\text { Schulz rating: randomisation B; allocation concealment B; selection bias B; blinding A. }\end{array}$} \\
\hline \multicolumn{3}{|l|}{ Risk of bias } \\
\hline Item & Authors' judgement & Description \\
\hline Allocation concealment? & Unclear & B - Unclear \\
\hline
\end{tabular}

\section{Laitinen 1981}

Methods $\quad$ Randomised controlled trial comparing adverse effects and efficacy of scopolamine, scopolamine + ephedrine and placebo for preventing seasickness.

Participants 30 male naval cadets aged 20 to 24 years. Participants with heart disease, hypertension, central nervous system disease, untreated angle closure glaucoma or prostate hypertrophy were excluded.

Interventions

Gelatinous capsules of either scopolamine hydrobromide $(0.3 \mathrm{mg})$, scopolamine hydrobromide + ephedrine hydrochloride $(25 \mathrm{mg})$, or placebo administered 3 times a day at 5-6 hour intervals over 5 days for prophylactic treatment of seasickness during crossing of Baltic and North Seas.

Outcomes

Subjective grading of efficacy of treatment and side effects.

Notes

No alcohol or central nervous depressants were allowed during the study. Participants were provided with three suppositories of $100 \mathrm{mg}$ pyridoxine hydrochloride as supplementary medication if required.

Schulz rating: randomisation A; allocation concealment B; selection bias B; blinding A. 
Laitinen 1981 (Continued)

\section{Risk of bias}

\begin{tabular}{|c|c|c|}
\hline Item & Authors' judgement & Description \\
\hline Allocation concealment? & Unclear & B - Unclear \\
\hline
\end{tabular}

Nuotto 1983

\begin{tabular}{|c|c|c|}
\hline Methods & \multicolumn{2}{|c|}{$\begin{array}{l}\text { Three placebo-controlled randomised trials comparing the psycho-physiological effects of scopolamine } \\
\text { and ephedrine in the prevention of motion sickness. }\end{array}$} \\
\hline Participants & \multicolumn{2}{|c|}{58 young, healthy male volunteers. } \\
\hline Interventions & \multicolumn{2}{|c|}{$\begin{array}{l}\text { Study 1: Intravenous scopolamine }(7.6 \mathrm{mg} / \mathrm{kg}) \text { or Intravenous placebo }(0.9 \% \mathrm{Nacl}) \text {; Studies II and III: } \\
\text { oral doses of scopolamine hydrobromide }(0.3 \mathrm{mg}, 0.9 \mathrm{mg}) \text { ephedrine }(25 \mathrm{mg}) \text {, combined scopolamine } \\
\text { hydrobromide and ephedrine }(0.3 \mathrm{mg}+25 \mathrm{mg} ; 0.9 \mathrm{mg}+25 \mathrm{mg}) \text { or placebo (lactose). }\end{array}$} \\
\hline Outcomes & \multicolumn{2}{|c|}{$\begin{array}{l}\text { A. Objective measurements of psycho-physiological effects of treatment measured by the following tests: } \\
\text { co-ordination, reactive skills, tapping speed, hand co-operation, speed anticipation, body sway, flicker } \\
\text { fusion, eso- and exophoria, nystagmus, near point of vision and pupil diameter, memory and learning } \\
\text { tasks, digit symbol substitution, Burdon Wiersma, blood pressure and heart rate. } \\
\text { B. Subjective assessments of current state using visual analogue rating scales. }\end{array}$} \\
\hline Notes & \multicolumn{2}{|c|}{ Schulz rating: randomisation $\mathrm{B}$; allocation concealment $\mathrm{A}$; selection bias $\mathrm{B}$; blinding $\mathrm{A}$. } \\
\hline \multicolumn{3}{|l|}{ Risk of bias } \\
\hline Item & Authors' judgement & Description \\
\hline Allocation concealment? & Yes & A - Adequate \\
\hline
\end{tabular}

\section{Offenloch 1986}

\begin{tabular}{l|l}
\hline Methods & $\begin{array}{l}\text { Randomised parallel-arm trial comparing transdermal scopolamine with oral antiemetic dimenhydrinate } \\
\text { for the prevention of motion sickness. }\end{array}$ \\
\hline Participants & 20 volunteers $(15$ male, 5 female) aged 20 to 47 years with proven motion sickness. \\
\hline Interventions & Transdermal scopolamine or oral dimenhydrinate taken prior to a one hour flight. \\
\hline Outcomes & $\begin{array}{l}\text { Subjective assessment of therapeutic effectiveness. } \\
\text { Incidence of adverse effects (tiredness, dry mouth, mouth dryness). }\end{array}$
\end{tabular}


Offenloch 1986 (Continued)

\begin{tabular}{|c|c|c|}
\hline Notes & \multicolumn{2}{|c|}{ Schulz rating: randomisation $\mathrm{B}$; allocation concealment $\mathrm{A}$; selection bias $\mathrm{B}$; blinding $\mathrm{A}$. } \\
\hline \multicolumn{3}{|l|}{ Risk of bias } \\
\hline Item & Authors' judgement & Description \\
\hline Allocation concealment? & Yes & A - Adequate \\
\hline
\end{tabular}

\section{Pingree 1994}

Methods Randomised, double-blind trial comparing scopolamine with cinnarizine in the prevention and treatment of seasickness.

Participants 179 healthy male volunteer personnel with a history of seasickness serving on two warships.

Interventions Prophylactic treatment of seasickness with gelatin capsules containing either scopolamine (or cinnarizine. Treatment was dispensed 4 hours prior to nauseogenic ship motion and continued at 6 hour intervals. Dosage information was not provided.

Outcomes $\quad 6$ hour intervals of subjective scores for a range of symptoms including: seasickness, headache, stomach awareness, drowsiness, dry mouth, visual disturbance, performance impairment and number of vomiting events.

Notes Schulz rating: randomisation B; allocation concealment B; selection bias B; blinding A.

\section{Risk of bias}

\begin{tabular}{|c|c|c|}
\hline Item & Authors' judgement & Description \\
\hline Allocation concealment? & Unclear & B - Unclear \\
\hline
\end{tabular}

Price 1981

\begin{tabular}{l|l}
\hline Methods & $\begin{array}{l}\text { Four randomised double-blind, placebo-controlled clinical trials in the prevention and treatment of motion } \\
\text { sickness. }\end{array}$ \\
\hline Participants & $\begin{array}{l}161 \text { healthy men and women with a history of motion sickness. Participants ages ranged from } 16 \text { to } 55 \\
\text { years. }\end{array}$ \\
\hline Interventions & $\begin{array}{l}\text { Transdermal scopolamine }(0.5 \mathrm{mg}) \text { delivered constantly over } 72 \text { hours), placebo or oral dimenhydrinate } \\
\text { taken either before or during a } 7-8 \text { hour cruise. }\end{array}$ \\
\hline Outcomes & $\begin{array}{l}\text { Subjective reporting of symptoms every } 1 \text { or } 2 \text { hours during exposure to motion (scale of } 0 \text { to 6) and } \\
\text { occurrence of dry mouth, drowsiness and blurred vision. }\end{array}$
\end{tabular}


Price 1981 (Continued)

\begin{tabular}{|c|c|c|}
\hline Notes & \multicolumn{2}{|c|}{$\begin{array}{l}\text { Subjects who requested extra medication received supplemental medication of } 200 \text { micrograms of intra- } \\
\text { muscular scopolamine hydrobromide. } \\
\text { Schulz rating: randomisation B; allocation concealment B; selection bias B; blinding A. }\end{array}$} \\
\hline \multicolumn{3}{|l|}{ Risk of bias } \\
\hline Item & Authors' judgement & Description \\
\hline Allocation concealment? & Unclear & B - Unclear \\
\hline
\end{tabular}

\section{Tokola 1984}

\begin{tabular}{|c|c|c|}
\hline Methods & \multicolumn{2}{|c|}{$\begin{array}{l}\text { Randomised placebo-controlled, double-blind trials comparing efficacy of scopolamine alone or with } \\
\text { ephedrine for prevention of seasickness. }\end{array}$} \\
\hline Participants & \multicolumn{2}{|c|}{28 healthy naval volunteers. } \\
\hline Interventions & \multicolumn{2}{|c|}{$\begin{array}{l}\text { Identical capsules of either scopolamine hydrobromide }(0.3 \mathrm{mg}) \text {, scopolamine hydrobromide }(0.3 \mathrm{mg})+ \\
\text { ephedrine hydrochloride }(0.25 \mathrm{mg}) \text {, or placebo administered } 3 \text { hours prior to sailing exercise (of } 24 \text { hour } \\
\text { duration) and then every } 6 \text { hours. }\end{array}$} \\
\hline Outcomes & \multicolumn{2}{|c|}{ Subjective rating of seasickness and side effects. } \\
\hline Notes & \multicolumn{2}{|c|}{$\begin{array}{l}\text { Participants were provided with five suppositories of pyridoxine hydrochloride } 100 \mathrm{mg} \text { to be taken if } \\
\text { necessary. A second trial is reported in this study. This trial is excluded. } \\
\text { Schulz rating: randomisation B; allocation concealment B; selection bias B; blinding A. }\end{array}$} \\
\hline \multicolumn{3}{|l|}{ Risk of bias } \\
\hline Item & Authors' judgement & Description \\
\hline Allocation concealment? & Unclear & B - Unclear \\
\hline
\end{tabular}

Uijdehaage 1993

Methods Randomised controlled trial comparing scopolamine with methscopolamine and placebo for physiological parameter measurements and prevention of motion sickness symptoms.

Participants 60 male college students (mean age 19.7 years) who were susceptible to vection-induced motion sickness Individuals with a history of neurological, cardiovascular or gastrointestinal disorders were not eligible.

Interventions

Solution of either scopolamine $(0.6 \mathrm{mg})$, meth- scopolamine $(2.5 \mathrm{mg})$ or placebo solution in $100 \mathrm{ml}$ of water taken approximately 1 hour prior to vection-induced motion sickness. 
Uijdehaage 1993 (Continued)

\begin{tabular}{|c|c|c|}
\hline Outcomes & \multicolumn{2}{|c|}{$\begin{array}{l}\text { Physiological measurements taken immediately after ingestion of treatment, after one hour and whilst } \\
\text { participant is seated in drum both whilst stationary and in rotation. Subjective motion sickness scores } \\
\text { taken every two minutes whilst in motion. }\end{array}$} \\
\hline Notes & \multicolumn{2}{|c|}{$\begin{array}{l}\text { Subjects were requested to not use any medication, alcohol or drugs } 24 \text { hours before testing, not to drink } \\
\text { caffeine-containing beverages } 12 \text { hours prior and to refrain from smoking, heavy exercise and eating } 4 \\
\text { hours prior to testing. } \\
\text { Schulz rating: randomisation B; allocation concealment B; selection bias B; blinding A. }\end{array}$} \\
\hline \multicolumn{3}{|l|}{ Risk of bias } \\
\hline Item & Authors' judgement & Description \\
\hline Allocation concealment? & Unclear & B - Unclear \\
\hline
\end{tabular}

\section{van Marion 1985}

\begin{tabular}{l|l} 
Methods & $\begin{array}{l}\text { Ransomised, controlled trial comparing the protective effect of transdermal scopolamine with transdermal } \\
\text { placebo against motion sickness during a } 7 \text { day sea voyage }\end{array}$ \\
\hline Participants & 49 health sailors aged 17 to 45 years with a previous history of motion sickness. \\
\hline Interventions & $\begin{array}{l}\text { Transdermal scopolamine (developed to release } 0.5 \text { mg constantly over } 72 \text { hours) or transdermal placebo } \\
\text { applied } 4 \text { hours prior to departure on a } 7 \text { day sea voyage. Patches were removed after } 72 \text { hours. }\end{array}$ \\
\hline Outcomes & $\begin{array}{l}\text { Subjective record of motion sickness symptoms (cold sweating, pallor, nausea and vomiting), drowsiness } \\
\text { and ability to perform tasks on a visual analog scale on days } 1,2,3,4 \text { and } 6 .\end{array}$ \\
$\begin{array}{l}\text { Subjective reporting of side effects. } \\
\text { Objective phyiological measurements recorded on days } 1,4 \text { and } 6 . \\
\text { Performance on an information processing task the day prior to departure and on Day } 1 .\end{array}$ \\
\hline Notes & $\begin{array}{l}\text { No restraints in washing or bathing were imposed. Subjects received } 50 \text { mg cyclizine tablets as supplemental } \\
\text { medication on request. } \\
\text { Schulz rating: randomisation B; allocation concealment B; selection bias B; blinding A. }\end{array}$ \\
\hline
\end{tabular}

\section{Risk of bias}

\begin{tabular}{|c|c|c|}
\hline Item & Authors' judgement & Description \\
\hline Allocation concealment? & Unclear & B - Unclear \\
\hline
\end{tabular}


Characteristics of excluded studies [ordered by study ID]

\begin{tabular}{|c|c|}
\hline Aizikov 1985 & $\begin{array}{l}\text { ALLOCATION } \\
\text { No mention of how subjects were assigned to treatment conditions }\end{array}$ \\
\hline Bodo 1982 & $\begin{array}{l}\text { ALLOCATION } \\
\text { Not randomised }\end{array}$ \\
\hline Brand 1967 & $\begin{array}{l}\text { ALLOCATION } \\
\text { Cross-over design was used }\end{array}$ \\
\hline Brand 1969 & $\begin{array}{l}\text { ALLOCATION } \\
\text { Cross-over design was used }\end{array}$ \\
\hline Cipriani 1987 & $\begin{array}{l}\text { ALLOCATION } \\
\text { Randomised } \\
\text { PARTICIPANTS } \\
\text { Included patients with peripheral vestibular vertigo, not motion sickness }\end{array}$ \\
\hline Cirillo 1986 & $\begin{array}{l}\text { ALLOCATION } \\
\text { Not randomised }\end{array}$ \\
\hline Estrada 2007 & $\begin{array}{l}\text { ALLOCATION } \\
\text { Cross-over design was used }\end{array}$ \\
\hline Galle 1988 & $\begin{array}{l}\text { ALLOCATION } \\
\text { No mention of how subjects were assigned to treatment conditions }\end{array}$ \\
\hline Glaznikov 1992 & $\begin{array}{l}\text { ALLOCATION } \\
\text { No mention of how subjects were assigned to treatment conditions } \\
\text { PARTICIPANTS } \\
\text { Included participants with lowered vestibule-vegetative equilibrium }\end{array}$ \\
\hline Gordon 2001 & $\begin{array}{l}\text { ALLOCATION } \\
\text { Cross-over design was used }\end{array}$ \\
\hline Gowans 2000 & $\begin{array}{l}\text { ALLOCATION } \\
\text { Cross-over design was used }\end{array}$ \\
\hline Hordinsky 1982 & $\begin{array}{l}\text { ALLOCATION } \\
\text { Cross-over design was used }\end{array}$ \\
\hline Howland 2006 & $\begin{array}{l}\text { ALLOCATION } \\
\text { Cross-over design was used }\end{array}$ \\
\hline
\end{tabular}


(Continued)

\begin{tabular}{|c|c|}
\hline Ilyina 1986 & $\begin{array}{l}\text { ALLOCATION } \\
\text { No mention of how subjects were assigned to treatment conditions }\end{array}$ \\
\hline Klocker 2001 & $\begin{array}{l}\text { ALLOCATION } \\
\text { Cross-over design was used }\end{array}$ \\
\hline Norfleet 1992 & $\begin{array}{l}\text { ALLOCATION } \\
\text { Cross-over design was used }\end{array}$ \\
\hline Pyyko 1984 & $\begin{array}{l}\text { ALLOCATION } \\
\text { Cross-over design was used }\end{array}$ \\
\hline Sabato 1987 & $\begin{array}{l}\text { ALLOCATION } \\
\text { No control group present }\end{array}$ \\
\hline Vigliano 1986 & $\begin{array}{l}\text { ALLOCATION } \\
\text { No mention of how subjects were assigned to treatment conditions }\end{array}$ \\
\hline Vigliano 1987 & $\begin{array}{l}\text { ALLOCATION } \\
\text { No mention of how subjects were assigned to treatment conditions }\end{array}$ \\
\hline Wang 1990 & $\begin{array}{l}\text { ALLOCATION } \\
\text { No mention of how subjects were assigned to treatment conditions }\end{array}$ \\
\hline Wolf 1987 & $\begin{array}{l}\text { ALLOCATION } \\
\text { Not randomised }\end{array}$ \\
\hline
\end{tabular}


DATA AND ANALYSES

Comparison 1. Prevention of sickness symptoms (nausea)

\begin{tabular}{lcccc} 
Outcome or subgroup title & $\begin{array}{c}\text { No. of } \\
\text { studies }\end{array}$ & $\begin{array}{c}\text { No. of } \\
\text { participants }\end{array}$ & Statistical method & Effect size \\
\hline $\begin{array}{l}\text { 1 Scopolamine vs placebo } \\
\begin{array}{l}\text { Scopolamine vs scopolamine + } \\
\text { ephedrine }\end{array}\end{array}$ & 5 & 165 & Risk Ratio (M-H, Random, 95\% CI) & $0.48[0.32,0.73]$ \\
\hline
\end{tabular}

\section{Comparison 2. Prevention of vomiting}

\begin{tabular}{lcccc} 
Outcome or subgroup title & $\begin{array}{c}\text { No. of } \\
\text { studies }\end{array}$ & $\begin{array}{c}\text { No. of } \\
\text { participants }\end{array}$ & Statistical method & Effect size \\
\hline $\begin{array}{l}\text { Scopolamine vs scopolamine }+ \\
\text { ephedrine }\end{array}$ & 2 & 40 & Risk Ratio (M-H, Random, 95\% CI) & $1.31[0.28,6.00]$ \\
\hline
\end{tabular}

\section{Comparison 3. Adverse event: drowsiness}

\begin{tabular}{lcccc} 
Outcome or subgroup title & $\begin{array}{c}\text { No. of } \\
\text { studies }\end{array}$ & $\begin{array}{c}\text { No. of } \\
\text { participants }\end{array}$ & Statistical method & Effect size \\
\hline 1 Scopolamine vs placebo & 2 & 60 & Risk Ratio (M-H, Random, 95\% CI) & $1.42[0.79,2.56]$ \\
\hline
\end{tabular}

\section{Comparison 4. Adverse events: blurred vision}

\begin{tabular}{lcccc} 
Outcome or subgroup title & $\begin{array}{c}\text { No. of } \\
\text { studies }\end{array}$ & $\begin{array}{c}\text { No. of } \\
\text { participants }\end{array}$ & Statistical method & Effect size \\
\hline 1 Scopolamine vs placebo & 2 & 89 & Risk Ratio (M-H, Fixed, 95\% CI) & $2.73[0.89,8.37]$ \\
\hline
\end{tabular}




\section{Analysis I.I. Comparison I Prevention of sickness symptoms (nausea), Outcome I Scopolamine vs placebo.}

\begin{tabular}{|c|c|c|c|c|c|}
\hline \multicolumn{6}{|c|}{ Comparison: I Prevention of sickness symptoms (nausea) } \\
\hline \multicolumn{6}{|c|}{ Outcome: I Scopolamine vs placebo } \\
\hline \multirow[t]{2}{*}{ Study or subgroup } & Scopolamine & Placebo & Risk Ratio & Weight & Risk Ratio \\
\hline & $\mathrm{n} / \mathrm{N}$ & $\mathrm{n} / \mathrm{N}$ & M-H,Random, $95 \% \mathrm{Cl}$ & & M-H,Random, $95 \% \mathrm{Cl}$ \\
\hline Attias 1987 & $4 / 10$ & $5 / 10$ & $\rightarrow-$ & $17.4 \%$ & $0.80[0.30,2.13]$ \\
\hline Laitinen 1981 & $4 / 23$ & $10 / 24$ & 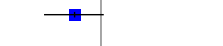 & $16.4 \%$ & $0.42[0.15,1.14]$ \\
\hline Price 1981 & $5 / 10$ & $10 / 10$ & 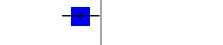 & $45.7 \%$ & $0.52[0.29,0.96]$ \\
\hline Tokola 1984 & $3 / 21$ & $9 / 17$ & $\longrightarrow$ & $12.9 \%$ & $0.27[0.09,0.84]$ \\
\hline Uijdehaage 1993 & 2/20 & $6 / 20$ & $\longrightarrow$ & $7.7 \%$ & $0.33[0.08,1.46]$ \\
\hline Total $(95 \% \mathrm{CI})$ & 84 & 81 & $\bullet$ & $100.0 \%$ & $0.48[0.32,0.73]$ \\
\hline \multicolumn{6}{|c|}{ Total events: 18 (Scopolamine), 40 (Placebo) } \\
\hline \multicolumn{6}{|c|}{ Heterogeneity: $\mathrm{Tau}^{2}=0.0 ; \mathrm{Chi}^{2}=2.57, \mathrm{df}=4(\mathrm{P}=0.63) ; \mathrm{I}^{2}=0.0 \%$} \\
\hline \multicolumn{6}{|c|}{ Test for overall effect: $Z=3.50(P=0.00046)$} \\
\hline
\end{tabular}

\section{Analysis I.2. Comparison I Prevention of sickness symptoms (nausea), Outcome 2 Scopolamine vs scopolamine + ephedrine.}

Review: Scopolamine (hyoscine) for preventing and treating motion sickness

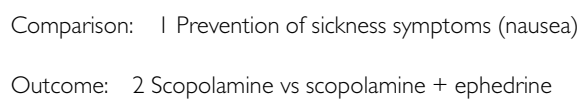

\begin{tabular}{|c|c|c|c|c|c|}
\hline Study or subgroup & Scopolamine & Scopolamine + ephedr & Risk Ratio & Weight & $\begin{array}{c}\text { Risk Ratio } \\
\text { M-H Random } 95 \% \text { Cl }\end{array}$ \\
\hline & $n / N$ & $\mathrm{n} / \mathrm{N}$ & M-H,Random,95\% Cl & & M-H,Random,95\% Cl \\
\hline Laitinen 1981 & $4 / 10$ & $7 / 10$ & 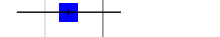 & $46.4 \%$ & $0.57[0.24,1.35]$ \\
\hline Tokola 1984 & $5 / 10$ & $6 / 10$ & $\square$ & $53.6 \%$ & $0.83[0.37,1.85]$ \\
\hline
\end{tabular}

Total (95\% CI)

20

20

$100.0 \%$

$0.70[0.39,1.26$ ]

Total events: 9 (Scopolamine), 13 (Scopolamine + ephedr)

Heterogeneity: Tau $^{2}=0.0 ; \mathrm{Chi}^{2}=0.40, \mathrm{df}=\mathrm{I}(\mathrm{P}=0.53) ; \mathrm{I}^{2}=0.0 \%$

Test for overall effect: $Z=1.19(P=0.23)$

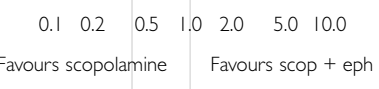


Analysis 2.I. Comparison 2 Prevention of vomiting, Outcome I Scopolamine vs scopolamine + ephedrine.

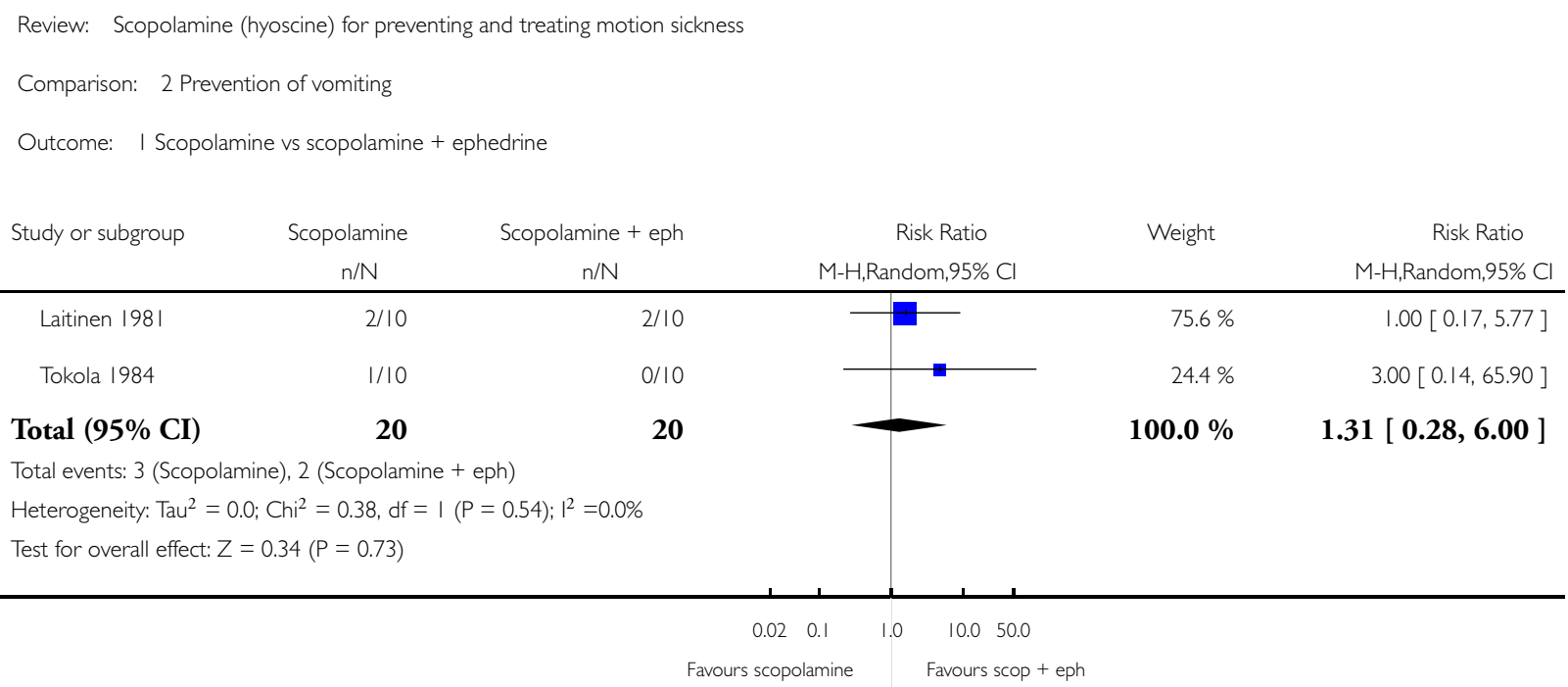

Analysis 3.I. Comparison 3 Adverse event: drowsiness, Outcome I Scopolamine vs placebo.

Review: Scopolamine (hyoscine) for preventing and treating motion sickness

Comparison: 3 Adverse event: drowsiness

Outcome: I Scopolamine vs placebo

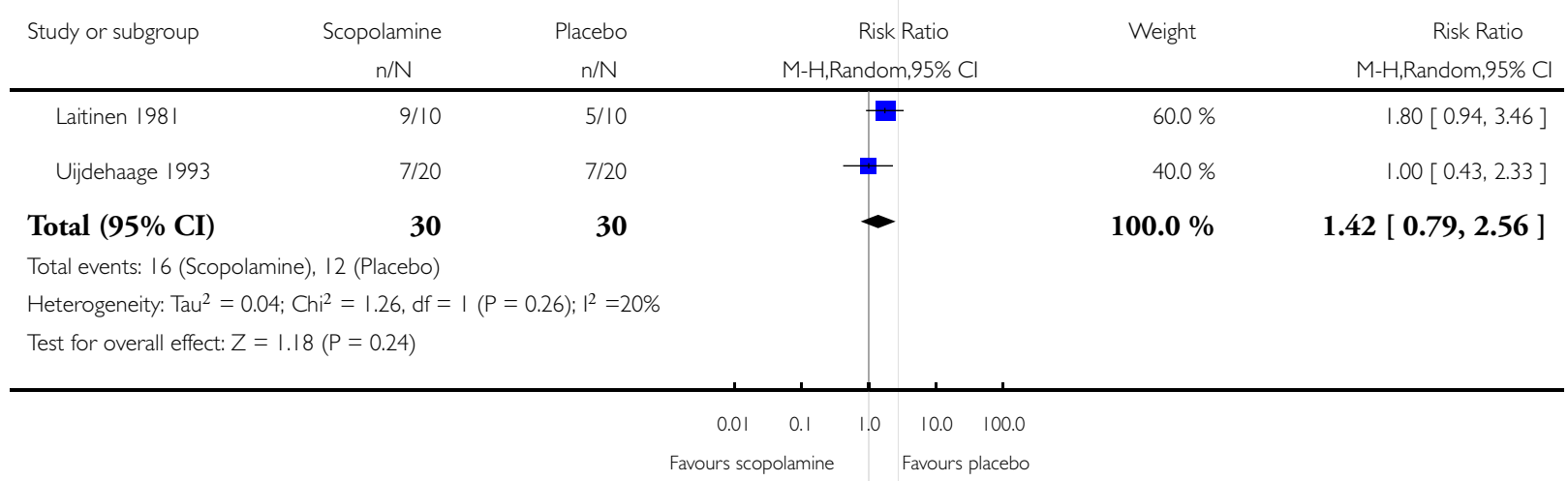




\section{Analysis 4.I. Comparison 4 Adverse events: blurred vision, Outcome I Scopolamine vs placebo.}

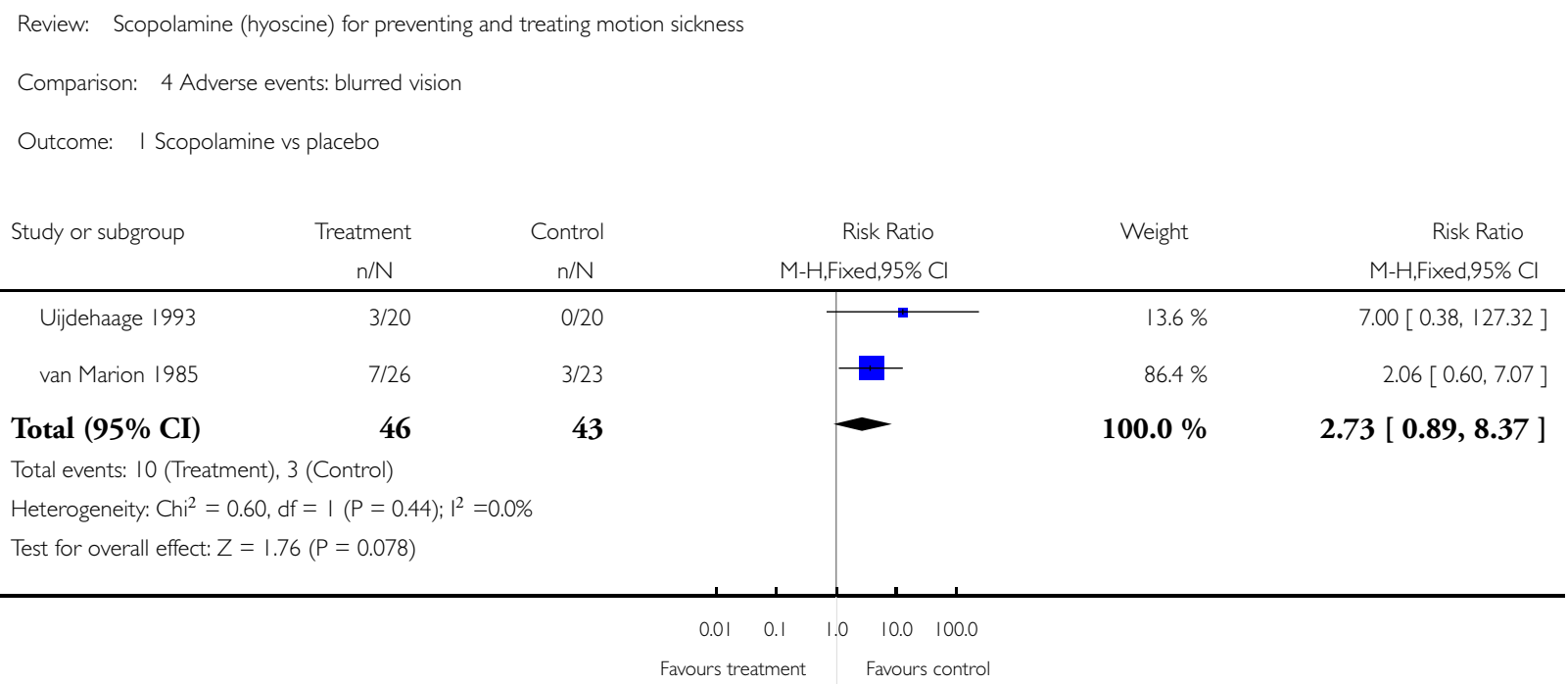

\section{A P P E D I C ES}

\section{Appendix I. Search strategy for CENTRAL}

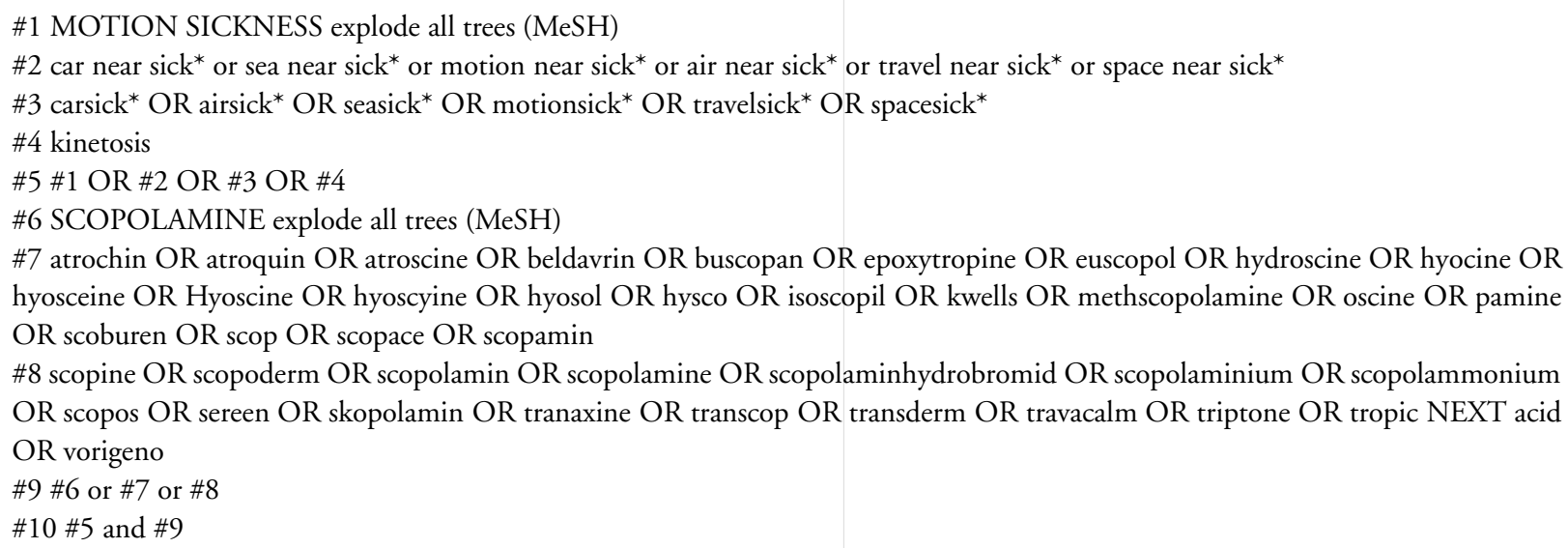

\section{F E E D B A C K}




\section{Comment 18/07/06}

\section{Summary}

Feedback:

1. The review does not examine how the effects of scopolamine (S) vary with the route of administration and the dose, nor does it describe the time course of the effects - although data relevant to these aspects are reported in most or all the included studies.

2. Doses and the timing of observations made in the studies are not given in the Table of Characteristics of included studies. They are needed to make clear what was done. Where doses are mentioned it is not stated whether they refer to $S$ base, or to $S$ hydrobromide that makes a big difference.

3. The clinical pharmacology of $S$ needs to be considered in the discussion. Four papers with relevant data, some of which should be included in the review, are:

a) Herxheimer A. A comparison of some atropine-like drugs in man. Br J Pharmacol 1958;13,184-192. This study measured effects of three different doses of $S$ given subcutaneously in healthy people, using an incomplete block design.

b) Brand JJ et al. Hyoscine and cyclizine as motion sickness remedies. Br J Pharmacol 1967;30, 463.

c) Brand JJ et al. Side-effects of 1-hyoscine and cyclizine studied by objective tests. Aerospace Med 1968; 39, 999.

d) Brand JJ, Whittingham P. Intramuscular hyoscine in control of motion sickness. Lancet 1970; 2, 232.

4. The review does not consider whether and how succesive trials learnt [or failed to learn] from or built on earlier ones. Did they address new questions? Did the method improve? Why were they done? It would be useful to highlight this by arranging the studies in chronological rather than alphabetical order.

5. The implications for research are rather vague. It would be helpful if the authors specified more precisely what are the most urgent questions that require research.

\section{Reply}

Response to comment 1 and 2 .

We have now included additional details in the Characteristics of Included Studies that describes the timing and dosage information where available for each study. We did not do sub-group analyses of these alternative administration methods due to small numbers. Response to comment 3.

We located each of the suggested studies however none of them were able to be included in the review due to the pre-established inclusion criteria. We have included comments on methods of delivery of scopolamine in the Discussion section of the review.

Response to comment 4.

We were unable to rearrange the order in which the studies appear in the inclusions table, however we have added a section to the discussion which comments on when the included studies were conducted and whether any changes occurred over time.

Response to comment 5 .

We have re-written this section.

\section{Contributors}

Name: Andrew Herxheimer

Email Address: a@herxheimer.net

Personal Description: Occupation Clinical Pharmacologist

Scopolamine (hyoscine) for preventing and treating motion sickness (Review) 


\section{WHAT'S NEW}

Last assessed as up-to-date: 17 May 2007.

26 October 2008 Amended Converted to new review format.

\section{H I S T O R Y}

Protocol first published: Issue 4, 2000

Review first published: Issue 3, 2004

23 May 2007 New citation required and conclusions have changed Substantive amendment

\section{CONTRIBUTIONS OFAUTHORS}

Vivienne Bernath: literature searching, review development, approval of final document.

Anneliese Spinks: study selection, data extraction, statistical analysis, drafting of written submissions, review development, approval of final document, guarantor of the paper.

Elmer Villanueva: study selection, data extraction, statistical analysis, drafting of written submissions, review development, approval of final document.

Jason Wasiak: study selection, drafting of written submissions, review development, updating of review, approval of final document.

\section{DECLARATIONSOF INTEREST}

None known.

\section{INDEX TERMS}

\section{Medical Subject Headings (MeSH)}

Motion Sickness [*drug therapy; prevention \& control]; Muscarinic Antagonists [adverse effects; *therapeutic use]; Randomized Controlled Trials as Topic; Scopolamine [adverse effects; ${ }^{*}$ therapeutic use]; Treatment Outcome 


\section{MeSH check words}

Adult; Child; Humans 